\title{
Sprawozdanie z realizacji pierwszej części projektu pt. „Miejsca i motywacje tożsamości. Polacy na Kresach Wschodnich", Lwów, 11-17 V 2019 r.
}

W dniach 11-17 V 2019 r. zrealizowana została pierwsza część projektu badawczo-edukacyjnego „Miejsca i motywacje tożsamości. Polacy na Kresach Wschodnich”. Został on przygotowany przez studentów Wydziału Historycznego Uniwersytetu im. Adama Mickiewicza w Poznaniu, przy zaangażowaniu dr hab. Agnieszki Sawicz i prof. dr. hab. Piotra Okulewicza. Tematyka pierwszego etapu związana była ze zgłębieniem historii i aktualnej sytuacji współczesnego pogranicza polsko-ukraińskiego z jego centrum, jakim jest Lwów. Celem przedsięwzięcia było zapoznanie się z sytuacją mniejszości polskiej na dawnych kresach wschodnich Rzeczypospolitej i obecnym pograniczu polsko-ukraińskim. Istotnym elementem przeprowadzonych badań było poznanie i analiza relacji pomiędzy zamieszkującymi te obszary Polakami a innymi mniejszościami narodowymi czy religijnymi oraz pomiędzy Polakami a narodowością dominującą - Ukraińcami.

Podczas pobytu we Lwowie przede wszystkim zapoznaliśmy się z wielokulturowością miasta, szczególnie interesowały nas akcenty polskie. Już od pierwszego dnia pobytu zapoznawaliśmy się z centrum Lwowa, w tym zwiedziliśmy zabytkowy dworzec kolejowy oraz okolice placu Rynek. Drugiego dnia nasze badania, dzięki uprzejmości Pana Krzysztofa Szymańskiego, rozpoczęliśmy od wizyty w redakcji Kuriera Galicyjskiego. Dane nam było poznać kulisy działania polskojęzycznego dwutygodnika oraz redakcji radiowej i telewizyjnej. „Kurier Galicyjski” przybliża czytelnikom, słuchaczom i widzom sytuację mniejszości polskiej na Wschodzie, współczesne relacje polsko-ukraińskie, prezentuje sytuację w Polsce oraz dzieje naszego kraju. Przygotowuje także filmy dokumentalne, których przedstawienie był 
by w przyszłości możliwe na naszym Wydziale. Przedstawiają one aktualną sytuację mniejszości polskiej zarówno na Ukrainie, jak i na pograniczach ukraińskich, w tym rumuńskiej Bukowinie, stanowiąc unikatowe źródło wiedzy na ten temat. Następnie udaliśmy się, wraz z przewodnikiem - panem Szymańskim, na zwiedzanie miasta. Skierowaliśmy się do starego Kasyna Szlacheckiego, po drodze poznając instytucje naukowe we Lwowie, m.in. Politechnikę Lwowską oraz Lwowski Uniwersytet Narodowy im. Iwana Franki, a także szkołę średnią nr 10 im. Marii Magdaleny, jedną z dwóch placówek z polskim językiem nauczania we Lwowie, przetrwały okres radziecki prowadząc pracę dydaktyczną. Poznaliśmy historię Parku Kościuszki, w którym znajduje się pomnik Iwana Franki - ukraińskiego poety i pisarza, uznawanego obok Tarasa Szewczenki za jednego z najwybitniejszych przedstawicieli ukraińskiej literatury. Pan Szymański zapoznał nas z historią Opery Lwowskiej, po czym udaliśmy się do Katedry Ormiańskiej, w której mogliśmy zetknąć się z kulturą jednej z mniejszości narodowych zamieszkującej Lwów. Nie sposób przy tym wymienić wszystkich informacji, jakie uzyskaliśmy przemierzając ulice miasta, w którym niemalże każda kamienica niesie z sobą bogatą historię. Pan Szymański precyzyjnie przybliżał nam losy mijanych obiektów, przede wszystkim ich polską przeszłość. Wyczerpująco odpowiadał przy tym na nasze pytania dotyczące losów Polaków i ich relacji z innymi grupami narodowościowymi czy religijnymi.

Zmierzając do lwowskiego rynku, zwiedziliśmy obiekty sakralne, m.in. rzymskokatolicką Bazylikę archikatedralną Wniebowzięcia Najświętszej Maryi Panny, Cerkiew Przemienienia Pańskiego oraz Katedrę Dominikańską. Zapoznaliśmy się przy tym z procesami, jakie towarzyszą zmianom we wnętrzach świątyń niegdyś rzymskokatolickich, a obecnie prawosławnych czy greckokatolickich, gdzie m.in. w przestrzeni nawy głównej pojawia się ikonostas. Uświadomienie sobie wagi kościołów, w tym Kościoła rzymskokatolickiego, dla funkcjonowania mniejszości polskiej było dla nas niezwykle cennym doświadczeniem. Możliwość naocznego przekonania się, jak silne są to problemy, była cennym uzupełnieniem dotychczas zdobytej wiedzy. Na terenie rynku mieliśmy możliwość poznać historię tzw. „Czarnej kamienicy” oraz kamienicy należącej do króla Jana III. Dowiedzieliśmy się także, gdzie znajdują się siedziby organizacji mniejszości polskiej (Towarzystwa Kultury Polskiej Ziemi Lwowskiej i Federacji Organizacji Polskich na Ukrainie) i jak wielkie znaczenie mają one dla kształtowania nie tylko życia Polaków, ale też ich relacji z przedstawicielami innych narodowości. „Lwowska” perspektywa problemów, z jakimi Polacy mieszkający na pograniczu muszą się mierzyć każdego dnia, a także tych, z którymi mierzyli się w czasach ZSRR i okresie transformacji, okazała się być w znacznej mierze od- 
mienna od tego, o czym dotychczas słyszeliśmy z mediów czy mogliśmy przeczytać w różnorodnych publikacjach prasowych. Potwierdziła się tym samym nasza teza, że bez możliwości zetknięcia się ze środowiskiem polskim nie sposób prowadzić badań nad przeszłością tych ziem czy zachodzącymi tam współcześnie procesami.

Trzeci dzień rozpoczęliśmy od zapoznania się z funkcjonowaniem Lwowskiej Narodowej Akademii Sztuk Pięknych, do której murów zostaliśmy zaproszeni dzięki uprzejmości kadry dydaktycznej. Naszymi przewodnikami byli prof. Mieczysław Maławski i prof. Bogdan Pikulicki. Mieliśmy możliwość poznania pracy studentów i wykładowców, gościliśmy także w pracowni renowacji ikon. Dużym ułatwieniem we wzajemnej komunikacji była dla nas doskonała znajomość języka polskiego zarówno profesorów uczelni, jak i studentów, co także jest jednym ze zjawisk charakterystycznych dla pogranicza. Przekonaliśmy się, że wiele z zamieszkujących je osób swobodnie posługuje się kilkoma językami, w tym, niezależnie od narodowości, językiem polskim. Owocne rozmowy z personelem uczelni oraz naszymi rówieśnikami, otworzyły możliwość przyszłej współpracy z Akademią Sztuk Pięknych we Lwowie.

Po wizycie na uczelni udaliśmy się w stronę dzielnicy Łyczaków, mijając po drodze dawną dzielnicę żydowską. Pamięć o ogromnej roli Żydów w tworzeniu kultury pogranicza, ale też o niełatwych relacjach tej społeczności z Polakami, jest niezwykle ważna dla analizy procesów zachodzących na styku kultur, religii i narodowości. W drodze na Cmentarz Łyczakowski zapoznaliśmy się m.in. z historią i stanem obecnym kościoła św. Antoniego, jednej z nielicznych świątyń, które po drugiej wojnie światowej służyły społeczności rzymskokatolickiej we Lwowie. Na terenie nekropolii łyczakowskiej interesowały nas pomniki zasłużonych Polsce postaci, m.in. Marii Konopnickiej, Gabrieli Zapolskiej, Juliana Konstantyna Ordona, Stefana Banacha czy Józefa Baczewskiego. Wizyta na cmentarzu Orląt Lwowskich unaoczniła nam, znany dotąd z podręczników i opracowań naukowych, ogrom poświęcenia naszych rówieśników, którzy walczyli za polskość Lwowa. Po powrocie do centrum miasta udaliśmy się do kościoła garnizonowego - Kościół św. Piotra i Pawła, klasztoru jezuitów oraz kościoła Bernardynów, w którym znajduje się państwowe archiwum historii Ukrainy.

Kolejnego dnia poznawaliśmy historię miejsca kaźni Polaków - więzienia przy ulicy Łąckiego, w którym NKWD brutalnie mordowało Polaków z Kresów Wschodnich. Zrekonstruowane pomieszczenia oficerów, cele czy miejsca odosobnienia więźniów ukazują nieludzki charakter tego obiektu. Po drodze wstąpiliśmy do dawnego Ossolineum, w którym dziś znajduje się biblioteka im. Wasyla Stefanyka, gdzie 
zapoznaliśmy się z tamtejszymi zachowanymi zbiorami. Następnie dane nam było zbadać wnętrze kościoła św. Marii Magdaleny, w którym znajduje się sala organowa z jednymi z największych organów na Ukrainie oraz mniej znane, niż zachowane w Katedrze Ormiańskiej, freski Jana Henryka Rosena. Poznaliśmy także historię konfliktu o prawo do własności tej świątyni, który do dziś pozostaje nierozwiązany i wpływa na relacje mniejszości polskiej z Ukraińcami. Tego dnia zgłębialiśmy również kulturę grekokatolicką, badając wnętrze Archikatedralnego soboru św. Jura we Lwowie, w tym krypty, w których pochowani są greckokatoliccy metropolici. Poznaliśmy też miejsce, w którym niegdyś spotykali się przedstawiciele tzw. Lwowskiej szkoły matematycznej, gdzie znajdywała się Kawiarnia Szkocka.

Cennym doświadczeniem było także uczestnictwo w koncercie w filharmonii lwowskiej, otwierającym międzynarodowy festiwal muzyczny „Wirtuozi”. Koncert prowadziła mieszkająca we Lwowie Polka, pani Zofia Iwanowa, córka jednej z najbardziej zasłużonych dla lwowskiej społeczności nauczycielek pani Marii Iwanowej, zaangażowanej, podobnie jak pani Zofia, w krzewienie polskości w tym mieście.

Ostatniego dnia „lwowskiej przygody” udaliśmy się na Wzgórze Zamkowe, gdzie znajduje się Kopiec Unii Lubelskiej, który został usypany z okazji trzechsetnej rocznicy jej zawarcia. Kolejnym punktem dnia była Kaplica Boimów - grobowiec znanej rodziny kupieckiej, która przybyła do Lwowa wraz z królem Stefanem Batorym. Budowla została wykonana w stylu manierystycznym i jest jedynym zachowanym obiektem w tym miejscu po byłym cmentarzu przy katedrze łacińskiej. Ostatnim miejscem, które zbadaliśmy, był Kościół św. Elżbiety. Ta świątynia jest przykładem sporu międzykonfesyjnego, gdyż wbrew woli miejscowych Polaków - rzymskich katolików, została przekazana w ręce społeczności greckokatolickiej, a konflikt, jaki rozgorzał wokół dzisiejszej cerkwi Olgi i Elżbiety, wpłynął negatywnie na relacje polsko-ukraińskie nie tylko na pograniczu ukraińskim, ale również odbił się szerokim echem po polskiej stronie granicy.

Braliśmy także udział jako słuchacze, w konferencji pt. „Ukraina w warunkach transformacji międzynarodowego systemu bezpieczeństwa”, która odbyła się w dniach 15-16 V 2019 r. Wśród zaproszonych gości znaleźli się politycy, dyplomaci, analitycy i naukowcy nie tylko z Polski i Ukrainy, ale też innych państw obszaru poradzieckiego i krajów członkowskich NATO. Dyskusja i referaty (także polsko i anglojęzyczne) pozwoliły nam lepiej zrozumieć złożoność relacji nie tylko polsko-ukraińskich, ale też miejsce Ukrainy w geopolityce. Nie pozostaje to bez wpływu na obecną sytuację mniejszości polskiej na Wschodzie, która jest istotnym czynnikiem mogącym oddziaływać na stosunki dwustronne. Przekonaliśmy się, że znajomość 
problemów, z jakimi borykają się Polacy na obszarze poradzieckim czy punktów spornych związanych z polityką historyczną Polski i Ukrainy, jest niezbędna dla skutecznej realizacji pracy naukowo-badawczej. Pozwala swobodniej i skuteczniej prowadzić rozmowy, często dotyczące niełatwych przecież zagadnień. To, co było dla nas szczególnie cenne, to możliwość wysłuchania argumentacji i racji przedstawianych przez prelegentów spoza Ukrainy i Polski.

Podróż do Lwowa unaoczniła nam dobitnie wagę osobistego kontaktu z przedstawicielami środowisk, o których historii i teraźniejszości chcielibyśmy mówić czy też prowadzić w przyszłości na ten temat badania. Była doskonałą możliwością poznania przeszłości dotychczas znanej nam jedynie z kart podręczników i publikacji popularnonaukowych skonfrontowania opinii wyrażanych przez stronę polską czy dziennikarzy z punktem widzenia Polaków na Wschodzie, Ukraińców czy przedstawicieli innych narodowości. Niewątpliwie zmusiło to nas do ponownego rozważenia wielu kwestii i weryfikacji swoich opinii czy wyobrażeń. Lwów jest wielokulturowym miastem, świadectwem tego są zachowane w dobrym stanie obiekty sakralne różnych grup wyznaniowych czy świecka architektura miasta. Mimo tej różnorodności Lwowa do dziś widoczne są wyraźne ślady jego polskiej przeszłości, na wielu kamienicach można znaleźć pamiątkowe tablice zapisane w języku polskim. Naród ukraiński ma w swojej historii wiele wybitnych jednostek, a obok ich pamięci pielęgnowana jest polska tradycja narodowa, czego przykładem są m.in. pomnik Adama Mickiewicza znajdujący się w centrum miasta czy pomniki wynalazców lampy naftowej - Ignacego Łukasiewicza i Jana Zeha. Trzeba jednak pamiętać, że należy uszanować narodowość ukraińską pomimo historycznej polskości tej aglomeracji, tradycji i kultury. Co niezwykle istotne, naocznie przekonaliśmy się, na jak szeroką skalę prowadzone są wspólne prace polsko-ukraińskie mające na celu ochronę lwowskich zabytków. Dzięki współpracy naukowców i konserwatorów zabytków ratowane są od zagłady bezcenne skarby kultury. Uświadomiliśmy też sobie wagę badań nad przeszłością tej ziemi, przede wszystkim zarejestrowania wspomnień Polaków, którzy mieszkają na dawnych polskich kresach. Z perspektywy historyka stanowią one bezcenne źródło, które należy ocalić dla przyszłych pokoleń. Nawiązane kontakty pozwalają nam zakładać, że w przyszłości będzie możliwe podjęcie szerszych prac przy wsparciu strony ukraińskiej i przedstawicieli mniejszości polskiej.

Joanna Przybylska, Marcin Janicki, Jakub Nitecki 